\title{
Evaluation of cases of spontaneous conceptions during COVID-19 outbreak and lock down: multicentric retrospective analytic study
}

\section{Deepak Patil*}

Department of Obstetrics and Gynaecology, Command Hospital Air Force, Bangalore, Karnataka, India

Received: 04 January 2022

Revised: 07 February 2022

Accepted: 08 February 2022

\section{*Correspondence:}

Dr. Deepak Patil,

E-mail: deepakaarav6@gmail.com

Copyright: ( $)$ the author(s), publisher and licensee Medip Academy. This is an open-access article distributed under the terms of the Creative Commons Attribution Non-Commercial License, which permits unrestricted non-commercial use, distribution, and reproduction in any medium, provided the original work is properly cited.

\begin{abstract}
Background: With lockdown and cessation of non essential, life saving treatment options couples registered at ART centres were dismayed. The aspirations of numerous couples and their families were left in a lurch. Unexpectedly cases of spontaneous conceptions in this pool of patients were a ray of hope.

Methods: In this multicentric retrospective analytic study, we evaluated all cases of spontaneous pregnancies and compared them with the cohort of couples registered at our ART centers. The objective of the study was to study impact of pandemic on ART registered couples.

Results: Comparisons showed that the patients who had conceived were younger with a shorter duration of infertility. More of unexplained infertile patients conceived as compared to those with known etiology. Genital tuberculosis remained constant subset of patient who conceived spontaneously as before.

Conclusions: Age and duration of infertility remains important prognostic indicator for spontaneous conception in Infertile couples. The pandemic had positive impact on conception rate in our clientele.
\end{abstract}

Keywords: Spontaneous conceptions, Lockdown, Corona virus

\section{INTRODUCTION}

The Corona virus pandemic is an extraordinary global emergency. Treatment which is not essential for life saving had to take a backseat. ESHRE, FOGSI and other governing bodies have issued guideline to curtain ART treatment. Decreased sperm count and motility is seen after 3 months of COVID Infection. Vertical transmission has also been reported. ${ }^{1}$ Studying impact on fertility is essential as the virus continued to be found in very low load till a year after infection. Being RNA enveloped virus it can remain viable in ultra low temperatures. In the long run risk of couriering the virus between ART centers with the vitrified semen sample needs to be addressed. $^{2}$
Spontaneous conception before, during and following ART treatment is always an unexpected positive outcome. Ali sami gurbuz et al had studied series of cases with spontaneous conception following unprotected intercourse around the time of ovum pickup in antagonist cycle with agonist trigger in freeze all cycles. ${ }^{3} \mathrm{~A}$ spontaneous conception avoids potential maternal-fetalassisted reproductive technology risks of IVF-ET cycle. ${ }^{4}$ Over time we saw an unexpected rise of spontaneous conceptions. The objective of this multicentric, retrospective observation study was to assess all these cases. We aim to study prognostic indicators for spontaneous conceptions. The same will be beneficial during counselling. 


\section{METHODS}

This is a multicentric, retrospective, analytic study of all patients registered at ART centers of Armed forces Tertiary care hospital. At registration, ART booklet with all demographic details and investigations were recorded and preserved at the centre's database.

\section{Selection criteria}

Records of all couples who conceived spontaneously during the lockdown were analyzed. Patients of Donor program were excluded from the study.

\section{Study design, location and duration}

Current study is a retrospective, analytic study conducted at multicentric locations; 151 base hospitals, Basistha ART Centre,151 Base Hospital, Guwahati and Navakriti ART Centre, Command Hospital Airforce, Bangalore. The study was conducted for one year from (1 January 2020 to 31 December 2020).

\section{Selection criteria}

Records of all couples who conceived spontaneously during the lockdown were analyzed. Patients of donor program were excluded from the study.

\section{Sample size and data analysis}

All patients registered for treatment at ART centre. Total of 329 couples were registered at these two centers. Data was analysed statistically with Chi square test. Over time we saw an unexpected rise of spontaneous conceptions. The objective of this multicentric, retrospective observation study was to assess all these cases. We aim to find common factors in couples achieving a spontaneous pregnancy. This will help us to council the couples about probability of same.

\section{RESULTS}

\section{Demographic data (age and BMI)}

Out of 329 couples 31 conceived spontaneously. Age distribution showed maximum conception in category of 25-30 years. Nearly $75 \%$ of all spontaneous conceptions were in patients below 30 years. Only $5 \%$ of patients in overweight and obese category conceived spontaneously. (Table 1-2).

\section{History parameters}

16 of 31 spontaneous pregnancies were in couples married for less than 3 years. Only $4 \%$ of couple married for more than 10 years conceived spontaneously. 22 of 31 spontaneous conception occurred in couples with secondary infertility (Table 3-4).
Table 1: Basic data.

\begin{tabular}{|ll|}
\hline Parameters & Results \\
\hline Observation period & January 20 to December 20 \\
\hline Number of patients & 329 \\
\hline $\begin{array}{l}\text { Spontaneous } \\
\text { conceptions }\end{array}$ & 31 \\
\hline PR & $9 \%$ \\
\hline
\end{tabular}

Table 2: Age distribution.

\begin{tabular}{|llll|}
\hline $\begin{array}{l}\text { Age category } \\
\text { (years) }\end{array}$ & $\mathbf{N}$ & $\begin{array}{l}\text { Number of } \\
\text { pregnancies }\end{array}$ & $\begin{array}{l}\text { PR } \\
(\%)\end{array}$ \\
\hline Below 25 & 63 & 6 & 9 \\
\hline $\mathbf{2 5 - 3 0}$ & 119 & 15 & 12 \\
\hline $\mathbf{3 0 - 3 5}$ & 73 & 7 & 9 \\
\hline $\mathbf{3 5 - 4 0}$ & 31 & 2 & 6 \\
\hline $\mathbf{4 0}$ plus & 43 & 1 & 2 \\
\hline Total & 329 & 31 & - \\
\hline
\end{tabular}

Table 3: BMI distribution.

\begin{tabular}{|llll|}
\hline BMI & N & Number of Pregnancies & PR $(\%)$ \\
\hline $\begin{array}{l}\text { Below } \\
\mathbf{1 8 . 5}\end{array}$ & 72 & 7 & 9 \\
\hline $\begin{array}{l}\mathbf{1 8 . 5} \text { to } \\
\mathbf{2 4 . 9}\end{array}$ & 139 & 17 & 12 \\
\hline $\mathbf{2 5}$ to 29.9 & 61 & 5 & 8 \\
\hline $\mathbf{3 0}+$ & 57 & 2 & 3 \\
\hline Total & 329 & 31 & - \\
\hline
\end{tabular}

\section{Treatment histories and etiology of infertility}

Total 8 of 31 spontaneous conception occurred in patients with no present active treatment. 2 of 26 patients on Anti tubercular therapy or had recently completed the therapy conceived spontaneously. 84 patients had undergone laparohysteroscopy for various indications in our cohort of 329 patients. 9 conceived spontaneously. 1 of 9 in this cohort had conversion to laparotomy for dense adhesions. 7 of 61 couples who had previously conceived with ART treatment conceived again. 5 of these had previous living issues. 14 of 95 couples with unexplained infertility conceived spontaneously. 3 patients with genital tuberculosis conceived spontaneously. 2 of these were on consolidation phase of 6 month course of ATT on INH and rifampicin. Ladies with anovulatory infertility had $8 \%$ pregnancy rate (Table 5-6)

\section{DISCUSSION}

Infertility is a disease that affects up to $15.5 \%$ of reproductive-aged couples. ${ }^{4}$ Cessation of all non life saving treatments due to the pandemic has affected all these couples and their aspirations. Taking a break from treatment has been double edged. For some couples it leads to spontaneous conception, whereas in others it leads to more heartache and stress. Stress of infertility 
may be further compounded because of cessation of all economic activity. Loss of job safety may be felt by some couples as a fall out of COVID crisis. ${ }^{5}$

\section{Table 4: Duration of infertility distribution.}

\begin{tabular}{|llll|}
\hline $\begin{array}{l}\text { Duration of } \\
\text { infertility (years) }\end{array}$ & $\mathbf{N}$ & $\begin{array}{l}\text { Number of } \\
\text { pregnancies }\end{array}$ & $\begin{array}{l}\text { PR } \\
(\%)\end{array}$ \\
\hline $\mathbf{1 - 3}$ & 131 & 16 & 12 \\
\hline $\mathbf{3 - 6}$ & 89 & 9 & 10 \\
\hline $\mathbf{6 - 9}$ & 48 & 3 & 6 \\
\hline $\mathbf{1 0}$ plus & 61 & 3 & 4 \\
\hline Total & 329 & 31 & - \\
\hline
\end{tabular}

Table 5: Type of infertility distribution.

\begin{tabular}{|llll|}
\hline $\begin{array}{l}\text { Type of } \\
\text { infertility (years) }\end{array}$ & N & $\begin{array}{l}\text { Number of } \\
\text { pregnancies }\end{array}$ & $\begin{array}{l}\text { PR } \\
(\%)\end{array}$ \\
\hline $\begin{array}{l}\text { Primary } \\
\text { infertility }\end{array}$ & 131 & 9 & 6 \\
\hline $\begin{array}{l}\text { Previous } \\
\text { abortion }\end{array}$ & 117 & 13 & 11 \\
\hline $\begin{array}{l}\text { Previous live } \\
\text { birth }\end{array}$ & 81 & 9 & 11 \\
\hline Total & 329 & 31 & - \\
\hline
\end{tabular}

Table 6: Treatment history distribution.

\begin{tabular}{|llll|}
\hline $\begin{array}{l}\text { Treatment } \\
\text { history }\end{array}$ & N & $\begin{array}{l}\text { Number of } \\
\text { pregnancies }\end{array}$ & $\begin{array}{l}\text { PR } \\
(\%)\end{array}$ \\
\hline No treatment & 109 & 8 & 7 \\
\hline ATT & 26 & 2 & 7 \\
\hline $\begin{array}{l}\text { h/o fertility } \\
\text { Enhancing } \\
\text { Surgery }\end{array}$ & 84 & 9 & 10 \\
\hline $\begin{array}{l}\text { Previous failed } \\
\text { ART }\end{array}$ & 49 & 5 & 10 \\
\hline $\begin{array}{l}\text { Previous } \\
\text { successful IVF }\end{array}$ & 61 & 7 & 11 \\
\hline Total & 329 & 31 & - \\
\hline
\end{tabular}

Cessation of ART services was essential in the pandemic circumstances. It was done to preserve resources for utilization at more required COVID care. More ever health care personnel were reallocated for duties related to COVID care. Globally being a new challenge data is not available about the behavior of the virus and its reproductive sequalae. ${ }^{6}$ Numerous studies have evaluated incidence of spontaneous conceptions in infertile couples. Generally the incidence is about 4-6\%.

Siladitya Bhattacharya et al in a population based cohort study found that with a 6 month delay in ART treatment, live birth rate (LBR) decreases by $11 \%$. LBR decreases further by $22 \%$ by delay of 12 month period in ladies above 40 years. Thus it is expected that due to cessation of ART services this subset of couples (above 40 years) valuable time of fertility is irretrievably lost. ${ }^{8}$ Though this additional waiting period due the COVID-19 proved less detrimental to ladies with unexplained infertility with lesser duration of infertility in our study population.

Table 8: Etiology distribution.

\begin{tabular}{|llll|}
\hline Etiology & N & $\begin{array}{l}\text { Number of } \\
\text { pregnancies }\end{array}$ & $\begin{array}{l}\text { PR } \\
(\%)\end{array}$ \\
\hline Unexplained & 101 & 14 & 13 \\
\hline Endometriosis & 31 & 1 & 3 \\
\hline Genital tuberculosis & 15 & 1 & 6 \\
\hline Male factor & 51 & 4 & 7 \\
\hline Anovulatory infertility & 29 & 3 & 10 \\
\hline Medical Co-morbidities & 39 & 4 & 10 \\
\hline Age factor & 31 & 2 & 6 \\
\hline Hydrosalphinx/fibroids & 32 & 2 & 6 \\
\hline Total & 329 & 31 & - \\
\hline
\end{tabular}

Most of spontaneous conceptions in infertile couples, nearly $80 \%$ occurs following reproductive counselling in the first six cycles. In patients with reasonably good chances of conception without major impairment of fertility, waiting for extended period in better option than instituting invasive and costly treatments. ${ }^{9}$ These are the subset of patients who are likely to benefit from waiting enforced by the pandemic crisis. In our study period of COVID lockdown, we saw 31 of 329 patients conceive spontaneously. In one year we saw a spontaneous conception rate of $9 \%$, compared to $4-6 \%$ previously. ART treatment is emotionally and physically challenging. It may affect sexuality negatively for both partners. In the lady primary infertility, young age and predominantly female factor for impaired fertility may lead to marital maladjustment and sexual dysfunction. ${ }^{10}$ Due to more time together during lockdown, it gave some couples more time to evolve and rediscover their relationship.

Due to reduction in industrial and vehicular pollution, because of industrial shut down and curfews imposed by the pandemic air quality has definitely improved. Among selected pollutant particulate matter below 10 micron and 2.5 micron saw a decline of more than $50 \%$ as compared to pre lockdown measures. There was a drastic reduction of levels of nitrogen dioxide $(-52 \%)$ and carbon monoxide $(-30 \%) .{ }^{11}$ Traffic related pollutants mainly sulphur dioxide, nitrogen dioxide and coarse particulate matter adversely affect fertility. ${ }^{12}$ This also helped achieve a healthier atmosphere to conceive. Exposure to air pollution reduces fertility rates and increases chances of miscarriage rate.

Age remains a prognostic indicator for successful treatment and spontaneous conceptions. Younger patient with unexplained infertility has good prognosis for achieving spontaneous conception. Female fertility start declining by 25-30 years and age at last child birth for spontaneous conceptions is 40-41y for most populations studied. ${ }^{13}$ Shimizu in a proportional hazard analysis found age to be most important variable for spontaneous conception. Less than $10 \%$ ladies over age of 34 years 
conceived spontaneously whereas spontaneous conception rate was $38 \%$ for ladies below the age of 27years. ${ }^{14}$ Demographic data of our cohort during COVID pandemic shows maximum cases of spontaneous pregnancy to be between $25-30$ years. 15 couples out of 119 falling in this age bracket conceived spontaneously. The Pregnancy rate in our cohort in this age group came to $12 \%$. In contrast only 1 of 43 couple above the age of 40 years conceived spontaneously during the lockdown.

Life style modification is an important cornerstone of infertility treatment. With lockdown couples had more time to invest in themselves. This may have helped improve health and metabolic aspects impairing fertility. Weight reduction decreases androgenic component hastening time to pregnancy. Shifting to healthier range of BMI increases the chances of spontaneous pregnancies. Grzegorczyk-Martin et al found weight reduction to improve chances of spontaneous conceptions. ${ }^{15}$ Obesity leads to anovulation, disordered endometrial growth, increased miscarriage rate and adversely impacts the neonatal outcome too. ${ }^{[16]}$ In our study we saw chances of spontaneous conception to be more for ladies in BMI group of $18-24 \mathrm{~kg} / \mathrm{m}^{2}$ as compared to overweight and obese category. 16 of 131 (PR 12\%) couples with less than 3years of infertility conceived spontaneously as compared to 3 of 61 couples (PR 4\%) in couples married for more than 10years. In our study we saw increased chances of spontaneous conception in young ladies with a shorter period of infertility. Chances of conception are increased with unexplained infertility and shorter partner relationship duration. As duration before conception increases, chances of spontaneous pregnancy further declines. ${ }^{13}$

Previous successful or unsuccessful treatment cycles were also predictors of future conception. Wynter et al in a study of more than 500 ladies found high spontaneous conception in ladies with secondary infertility. $30 \%$ and $40 \%$ ladies with previous ART and spontaneous conception respectively conceived spontaneously again during a follow up period of 4-6 years. In our study we saw 22 of 188 (PR 6\%) ladies with secondary infertility conceive spontaneously as compared to 9 of 131 (PR $11 \%$ ) ladies who never had a previous conception. ${ }^{17}$ Fertility enhancing surgery at diagnostic laparohysteroscopy improves the chances of spontaneous conception. Minor adhesisiolysis and fulguration of superficial endometriotic implants lead to spontaneous pregnancies in $37 \%$ of patients in $12-16$ mo. ${ }^{18}$ Both medical and surgical treatment of pelvic pathology arrests the progression of disease. ${ }^{19}$ In our study 9 of 84 (PR $10 \%$ ) ladies with previous history of fertility enhancing pelvic surgery conceived during the COVID crisis spontaneously.

COVID-19 crisis caused discontinuation of ART treatment cycles. In our cohort of patients 5 of 49 (PR $10 \%)$ with previous failed IVF cycles and 7 of $61(11 \%)$ with previous successful IVF outcomes conceived spontaneously during the lockdown. Troude in a retrospective cohort study of 8 centres's found a spontaneous pregnancy rate of $17 \%$ and $38 \%$ for couples with previous successful and unsuccessful IVF attempts respectively. In unsuccessful treated couples $60 \%$ conceived in 2-3 years spontaneously whereas it took 5-6 years for patients with previous treatment failure to achieve a pregnancy without any treatment. The probability of spontaneous pregnancy decreased with increase in number of previous IVF attempts. ${ }^{20}$ Wynter et al also found a high incidence of $40 \%$ in ladies with prior non ART conception as compared to $30 \%$ ladies with ART conception to conceive spontaneously in a follow up of 2 years. ${ }^{17}$ Similar to our study, they also found higher chances of spontaneous conception with unexplained infertility and shorter duration of cohabitation with partner. Certain factors like unexplained infertility have aspects not yet defined by available investigative and treatment modalities. These had maximum probability of conceiving spontaneously. ${ }^{20}$ Collins also found that treatment independent pregnancies occurred in $33 \%$ of 1145 infertile couples over 2-7 year follow up. $92 \%$ of these had unexplained or cervical factor infertility. ${ }^{21}$ With lockdown and work from home couples got more time to cohabitate. Improved bonding and psychological support has lead to a feeling of being cared and looked after. This improved the HPO axis and helped in anovulatory infertility. Reduction in stress is important to achieve conception. ${ }^{22}$ 14 of 101 couples achieved pregnancy in the category of unexplained infertility. This was the largest contributor in our cohort of patients. In our data analysis one of fifteen patients who had finished ATT within past 6 months conceived spontaneously. UN Jindal in a north India based study of more than 400 ladies on ATT for genital tuberculosis found a high spontaneous conception rate in couples with RT-PCR positive for mycobacterium tuberculosis. Chances of spontaneous pregnancy are maximum for ladies without residual damage to tube or endometrium. ${ }^{23}$

Ilacqua et al saw that both acute and chronic stress affect semen quality. They saw a $39 \%$ reduction in sperm count, $49 \%$ reduction in sperm motility following acute stress event. Stress event reduces the LH pulses thus reducing the testosterone production and quality of spermatogenesis. Stress also causes cortisol mediated apoptosis of leydig and sertoli cells. ${ }^{24}$ Due to lockdown and staggered working, the cumulative day to day stress might be lower as compared to non COVID times. Over 6-8 month of lockdown it aided healthier spermatogenesis. This might have helped improve semen quality to improve chances of spontaneous pregnancies. In our study we found, 3 of 51 couples with borderline male factor achieved spontaneous conception. Borderline male factor was defined as sperm count in the range of 10-15 million/ml. Reducing/stopping smoking and tobacco addiction helps reduce stressors for gametogensis. Due to pandemic and couple staying together there is constant positive reinforcement to give 
up addictions. This also improves chances of conceiving. Smoking directly affects preimplantation and implantation process with increased chances of abortion. In males it reduces the proportion of motile sperms and induces abnormal sperm morphology. ${ }^{25}$ SARS COVID can cause orchitis as a result of vasculitis. This is caused by altered coagulation and impaired vascularisation of testicular tissue. ${ }^{26}$ Male factor which is implied as a causal factor in $35-55 \%$ case may be more pronounced after the pandemic. It is also found in some studies, that borderline male factor not requiring ICSI in treatment cycle had increased chances of spontaneous pregnancies. ${ }^{20}$ Incidences of thyroid disorders are found more in infertile couples. Lady with raised TSH, above $3.7 \mathrm{miu} / \mathrm{ml}$ has blunted response to $\mathrm{LH}$ pulses. These in turn alters GNRH pulses leading to anovulatory dysfunction and impaired fertility. Thyroid auto immune (TAI) disorders are a reflection of immune imbalance impairing fertilization and implantation. ${ }^{27}$ In our population thyroid disorder had a prevalence of $6-8 \%$. Euthyroid status achieved with continued treatment during the pandemic may have contributed to spontaneous conceptions during the lockdown.

Fibroids may be incidental finding during evaluation of infertile lady. A sub mucosal fibroid by impairing endometrial blood supply and surface area for implantation may impair conception. ${ }^{28}$ In our study, one lady with $3 \mathrm{~cm}$ fundal, sub serous myoma conceived spontaneously. Improving glycemic control with better attention to self during COVID has also helped achieve pregnancy. In a meta analysis of 77 studies by Allotey pregnant ladies were less likely to report with cough and fever for COVID infection but if infected showed higher chances of severe acute respiratory syndrome. One fourth of all neonates born to COVID positive ladies required admission for neonatal care. ${ }^{29}$ Our study showed 4 of 39 patients (PR 10\%) with medical co morbidity conceived during lockdown. 2 had overt diabetes mellitus, one was hypothyroid and one patient had preexisting bronchial asthma. Increased frequency of sexual intercourse also helped achieve spontaneous conception. Enforced cohabitation due to lock down helped couple spends more time with each other. Fang et al found increased partner time and intimacy behavior during the pandemic lockdown. This also reflected in increased sexual frequency in married couples. ${ }^{30}$

Outcome of spontaneous conception and ART treatment conceptions are no different. The risks of preterm birth, SGA, need for neonatal intensive care and low APGAR scores remains same in infertile couple whatever the mode of conception. ${ }^{31}$ The cohort of our spontaneously conceived patients is unlikely to have a different obstetric outcome as compared to rest of infertile couples. Although, recent studies have also shown evidence of placental Covid disease. It is characterized by viraemia of placental trophoblast and chorionic villous microstructure. Placental vasculopathy due to COVID-19 might lead to severe IUGR if infected in early pregnancy. ${ }^{32}$ Inspite of hardship of COVID crisis a spontaneous conception brings about happiness. Spontaneous pregnancies have reduced anxiety and depression score as compared to ART treatment conception. ${ }^{33}$

\section{Limitations}

Limitations of current study were; sample size if increased by incorporating more infertile couples could make results more significant. Follow up of these pregnancies to study effect of corona virus on pregnancy was beyond the scope of this study. A longer observation could have added more relevance to the study.

\section{CONCLUSION}

Being an unknown and worldwide medical emergency COVID pandemic has far reaching consequences. In infertile couples the stress is further compounded by impact of the virus on germ cells. Spontaneous pregnancies are huge and welcome news for any couple. Our study shows that particular subset of infertile couples is favorable prognosis indicator for spontaneous conception. This will help us to identify and provide assurance to such couples. Young couples with unexplained infertility and well controlled medical co morbidity are especially favorable features for spontaneous conception in our cohort. The incidence of spontaneous conceptions highlights the need to council couples that even after failure of IVF-ET, they should not lose hope. Following a healthy life style and diet they must continue cohabitation to achieve a much awaited pregnancy. For couples not desiring further pregnancy counselling is essential about choice of contraception.

\section{ACKNOWLEDGEMENTS}

Author would like to thank all the nursing staff, PG residents, interns and supportive staffs. The authors are really grateful to all the participating ladies who consented to be part of the study.

\section{Funding: No funding sources \\ Conflict of interest: None declared}

Ethical approval: The study was approved by the Institutional Ethics Committee

\section{REFERENCES}

1. James S, Quinton K, McQueen DB, Kotlyar A, et al. Prior and novel coronaviruses, Coronavirus Disease 2019 (COVID-19), and human reproduction: what is known?. Fertil Steril. 2020;113(6):1140-9.

2. Yakass MB, Woodward B. COVID-19: should we continue to cryopreserve sperm during the pandemic? Reprod Biomed. 2020;40(6):905.

3. Gurbuz AS, Deveer R, Ozcimen N, Ozcimen EE, Lawrenz B, Banker M. Absence of luteal phase defect and spontaneous pregnancy in IVF patients despite 
GnRH-agonist trigger and "freeze all policy" without luteal phase support: a report of four cases. Gynecol Endocrinol. 2016;32(1):18-20.

4. Kawwass JF, Badell ML. Maternal and fetal risk associated with assisted reproductive technology. Obstet Gynecol. 2018;132(3):763-72.

5. Trinchant RM, Cruz M, Marqueta J, Requena A. Infertility and reproductive rights after the COVID19 pandemic. Reprod Biomed. 2020;41(2):151-3.

6. Rodriguee KA, Wallberg A, Wikander. A global recommendation for restrictive provision of fertility treatments during the COVID-19 pandemic. Acta Obstet Gynecol Scand. 2020;99(5):569-70.

7. Vardon D, Burban C, Collomb J, Stolla V, Erny R. Spontaneous pregnancies in couples after failed or successful in vitro fertilization. J Gynecol Obstet Biol Reprod (Paris). 1995;24(8):811-9.

8. Bhattacharya S, Maheshwari A, Ratna MB, Eekelen R. Prioritizing IVF treatment in the post-COVID 19 era: a predictive modelling study based on UK national data. Hum Reprod. 2021;36(3):666-75.

9. Gnoth C, Godehardt E, Frank-Herrmann P, Friol K, Tigges J, Freundl G. Definition and prevalence of subfertility and infertility. Hum Reprod. 2005;20(5): 1144-7.

10. Winkelman WD, Katz PP, Smith JF, Rowen TS, et al. The sexual impact of infertility among women seeking fertility care. Sex Med. 2016;4(3):e190-7.

11. Aitken RJ. COVID-19 and human spermatozoaPotential risks for infertility and sexual transmission? Andrology. 2021;9(1):48-52.

12. Mahato S, Pal S, Ghosh KG.Effect of lockdown amid COVID-19 pandemic on air quality of the megacity Delhi, India. Sci Total Environ. 2020;730:139086.

13. Vizcaíno MAC, González-Comadran M, Jacquemin B. Outdoor air pollution and human infertility: a systematic review. Fertil Steril. 2016;106(4):897-904.

14. Borght MV, Wyns C. Fertility and infertility: Definition and epidemiology. Clin Biochem. 2018;62:2-10.

15. Shimizu Y, Kodama H, Fukuda J, Murata M, Kumagai J, Tanaka T. Spontaneous conception after the birth of infants conceived through in vitro fertilization treatment Fertil Steril. 1999;71(1):35-9.

16. Grzegorczyk-Martin V, Fréour T, Finet ADB, Bonnet E. IVF outcomes in patients with a history of bariatric surgery: a multicenter retrospective cohort study. Hum Reprod. 2020;35(12):2755-62.

17. Talmor A, Dunphy B. Female obesity and infertility. Best Pract Res Clin Obstet Gynaecol. 2015;29(4):498506.

18. Wynter K, McMahon C, Hammarberg K, McBain J, Boivin J, Gibson F, Fisher J. Spontaneous conceptions within two years of having a first infant with assisted conception. Aust N Z J Obstet Gynaecol. 2013;53(5):471-6.

19. Younas K, Majoko F, Sheard K, Edwards C, Bunkheila A. Select and treat at laparoscopy and dye test improves the spontaneous pregnancy. Hum Fertil (Camb). 2014;17(1):56-9.
20. Ganesh AL, Chakravarty B. Spontaneous viable pregnancies in cervical and rectal endometriosis: a report of two cases. Fertil Steril. 2007;87(3):697.e1-4.

21. Troude P, Bailly E, Guibert J, Bouyer J, de la Rochebrochard E; DAIFI Group. Spontaneous pregnancies among couples previously treated by in vitro fertilization. Fertil Steril. 2012;98(1):63-8.

22. Collins JA, Wrixon W, Janes LB, Wilson EH. Treatment-independent pregnancy among infertile couples. N Engl J Med. 1983;309(20):1201-6.

23. Seibel MM, Taymor ML. Emotional aspects of infertility. Fertil Steril. 1982;37(2):137-45.

24. Jindal UN, Verma S, Bala Y. Favorable infertility outcomes following anti-tubercular treatment prescribed on the sole basis of a positive polymerase chain reaction test for endometrial tuberculosis. Hum Reprod. 2012;27(5):1368-74.

25. Ilacqua A, Izzo G, Emerenziani GP, Baldari C, Aversa A. Lifestyle and fertility: the influence of stress and quality of life on male fertility. Reprod Biol Endocrinol. 2018;16(1):115.

26. Stillman RJ, Rosenberg MJ, Sachs BP. Smoking and reproduction. Fertil Steril. 1986;46(4):545-66.

27. Corona G, Baldi E, Isidori AM, Paoli D, Pallotti F, De Santis L, et al. SARS-CoV-2 infection, male fertility and sperm cryopreservation: a position statement of the Italian Society of Andrology and Sexual Medicine (SIAMS) (Società Italiana di Andrologia e Medicina della Sessualità). J Endocrinol Invest. 2020;43(8): 1153-7.

28. Unuane D, Velkeniers B. Impact of thyroid disease on fertility and assisted conception. Best Pract Res Clin Endocrinol Metab. 2020;34(4):101378.

29. Pritts EA, Parker WH, Olive DL. Fibroids and infertility: an updated systematic review of the evidence. Fertil Steril. 2009;91(4):1215-23.

30. Mahdian S, Shahhoseini M, Moini A. COVID-19 Mediated by Basigin Can Affect Male and Female Fertility. Int J Fertil Steril. 2020;14(3):262-3.

31. Jing Y, Run-Qian L, Hao-Ran W, Hao-Ran C, Ya-Bin L, Yang G, Fei C. Potential influence of COVID19/ACE2 on the female reproductive system. Mol Hum Reprod. 2020;26(6):367-73.

32. Allotey J, Stallings E, Bonet M, Yap M, Chatterjee S, Kew T, et al. Clinical manifestations, risk factors, and maternal and perinatal outcomes of coronavirus disease 2019 in pregnancy: living systematic review and meta-analysis. BMJ. 2020;370:m3320.

33. Fang D, Peng J, Liao S, Tang Y, Cui W, Yuan Y, et al. An online questionnaire survey on the sexual life and sexual function of chinese adult men during the coronavirus disease 2019 epidemic. Sex Med. 2021; 9(1):100293.

34. Raatikainen K, Kuivasaari-Pirinen P, Hippeläinen M, Heinonen S. Comparison of the pregnancy outcomes of subfertile women after infertility treatment and in naturally conceived pregnancies. Hum Reprod. 2012; 27(4):1162-9.

35. Hsu AL, Guan M, Johannesen E, Stephens AJ, Khaleel N, Kagan N, et al. Placental SARS-CoV-2 in 
a pregnant woman with mild COVID-19 disease. J Med Virol. 2021;93(2):1038-44.

36. Tendais I, Figueiredo B. Parents' anxiety and depression symptoms after successful infertility treatment and spontaneous conception: does singleton/twin pregnancy matter? Hum Reprod. 2016; 31(10):2303-12.
Cite this article as: Patil D. Evaluation of cases of spontaneous conceptions during COVID-19 outbreak and lock down: multicentric retrospective analytic study. Int J Reprod Contracept Obstet Gynecol 2022;11:832-8. 